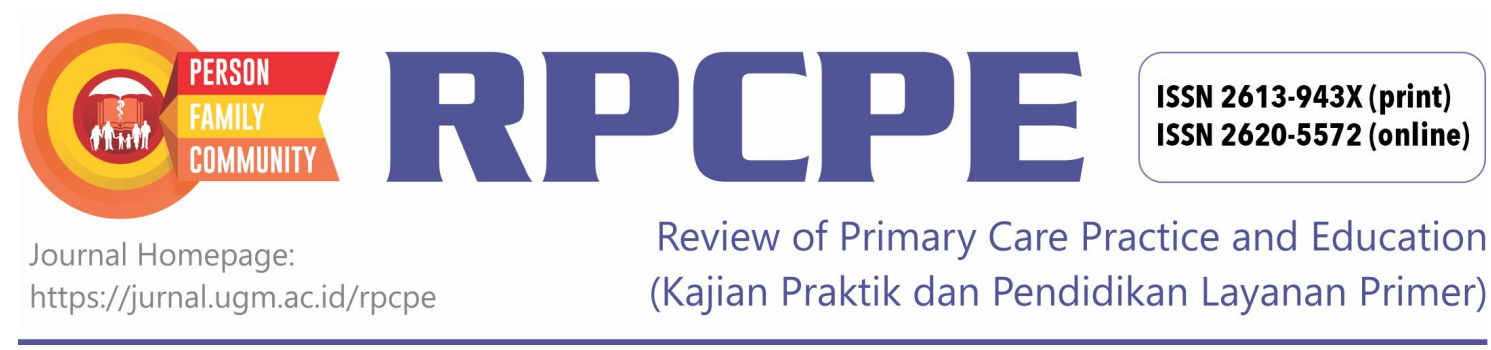

\title{
The Effect of Mental Health Training on Attitudes and Knowledge of Cadres in Early Detection of Mental Disorders in Tanjungsari Sub-district, Gunungkidul Regency
}

Nur Alifa Istiani ${ }^{1}$, Adi Heru Husodo², Mahar Agusno ${ }^{3}$

\author{
${ }^{1}$ Puskesmas Tanjungsari; Yogyakarta; Indonesia \\ ${ }^{2}$ Department of Family and Community Medicine; Faculty of Medicine, Public Health and Nursing; Universitas Gadjah Mada; \\ Indonesia \\ ${ }^{3}$ Department of Mental Health; Faculty of Medicine, Public Health and Nursing; Universitas Gadjah Mada; Indonesia
}

Corresponding Author:

Nur Alifa Istiani: Puskesmas Tanjungsari, Jl. Baron KM 12, Desa Kemiri, Kecamtan Tanjungsari, Kabupaten Gunungkidul, Yogyakarta - 55881, Indonesia

Email: alifaistiani@yahoo.com

To cite this article:

Istiani NA, Sutomo AH, Agusno M. The effect of mental health training on attitudes and knowledge of cadres in early detection of mental disorders in Tanjungsari sub-district, Gunungkidul regency. Rev Prim Care Prac and Educ. 2018; 1(3): 136-140.

\begin{abstract}
Background: In developing countries, the proportion of undetected mental disorders is still high. This is due to the lack of time and skill of primary health care providers in early detection and therapy. Community empowerment through cadres plays an important role in improving the early detection of mental disorders. Attitudes and knowledge of cadres are influenced by several factors such as the level of formal education, employment status, economic status and the level of knowledge gained through training. Objectives: This study aimed to determine the effect of mental health training on the attitude and knowledge of cadres in the early detection of mental disorders. Methods: This study was a quasi-experimental research with a pre and posttest design. The population in this research was all (posyandu) volunteer cadres in the working area of the Community and Primary Health Care Center Hargosari, Tanjungsari, amounting to 45 people. The sampling technique used in this study was total sampling. The research instrument used was the questionnaire. Data analysis used the Wilcoxon test for comparison of scores $(p<0.05)$. Results: The results of the mean value for pretest of knowledge $=13.44$ and posttest $=17.38$. Wilcoxon test showed there was a significant change in knowledge with the value $p=0.0000(<0.05)$. The results of the average value of pretest attitude $=36.71$ and posttest $=45.20$. Wilcoxon test showed there was a significant change in attitude with the value $p=0.0000(<0.05)$. Conclusion: In conclusion, there was a significant influence by providing health training on the attitude and knowledge of cadres in the early detection of mental disorders in Tanjungsari District, Gunungkidul Regency.
\end{abstract}

Keywords: Early detection, mental disorders, attitude, knowledge, cadre

\section{INTRODUCTION}

Mental health problems are one of the major causes of disability worldwide ${ }^{1}$. Although the discovery of new therapies for psychiatric disorders is highly developed, however, the proportion of undetected mental disorders is still high. Although mental disorders do not directly cause death, they can lead to great suffering in individuals, families, and communities ${ }^{2}$. In developing countries, this health burden can be due to the stigma associated with psychiatric problems so that people are reluctant to seek medical help. Several studies have emphasized that there a lack of training time and skill of primary care providers in early detection and therapy for mental disorders ${ }^{3}$.

In developed countries, mental health problems have become the cause of a large burden of disease. In 2020, it is predicted that unipolar depression will occupy the second rank in the cause of disease burden ${ }^{4}$. It is estimated that 26 million of the Indonesian population are mentally ill with the mildest symptoms being panic and anxiety ${ }^{5}$. The prevalence of severe mental illness in Indonesia by 2013 was 1.7 every thousand people. For the region of Yogyakarta, in 2013, the prevalence of severe mental disorders was 2.7 every 
thousand people ${ }^{6}$.

Early and accurate detection of mental health problems followed by good therapy and management can reduce the burden of health and social burden caused by mental disorders. Early detection has been proven to not only help to restore mental health quickly and thoroughly but also to integrate sufferers back into society in a better way ${ }^{7}$.

Community leaders and community health cadres are at the forefront of community-based health services. Previous research has shown that the empowerment of communities plays an important role in health promotion programs ${ }^{8}$.

The participation of cadres is influenced by several factors such as the level of formal education, employment status, economic status and the level of knowledge gained through training 9 . Cadres who take part in training have better knowledge and skills than cadres who have never attended training. Cadre knowledge about health, especially mental health will influence the behavior of cadres to participate in overcoming any health problems in the community ${ }^{10}$. To improve the effectiveness of training, audiovisual methods can be used in training. In addition, it can be accomplished by adding activities in the form of case studies regarding mental disorders so that mental health training is more optimal $^{11}$.

Based on the above background information, this study aimed to measure how mental health training in Tanjungsari District can influence the attitude and knowledge of mental health cadres for improving early detection of cases of mental disorders.

\section{METHODS}

This research was a quasi-experimental study with a pretest and posttest design. Variables were measured from posyandu volunteer cadres in the working area of
Community and Primary Health Care Center Hargosari, Tanjungsari.

The equipment used was a questionnaire about attitude and knowledge of mental disorders. Questions for knowledge used answers with a binominal scale with the answers: "right" and "wrong", while for attitude the Likert scale was used with four choices: "Strongly Agree", "Agree", "Disagree" and "Strongly Disagree". The questionnaire used in the validation correlates the score of each item with the total score in each construct. Items with a high correlation value indicate that the item has high validity. Correlation analysis used was a Pearson Moment correlation test. For the reliability of the questionnaire, Cronbach Alpha was tested, where the reliability of a variable construct was considered good if the Cronbach Alpha value was $>0.60$.

The subjects filled out questionnaires to see attitudes and knowledge before and after training on mental disorders. The inclusion criteria of the subjects of this study cadre never participated in cadre training on previous mental health. Exclusion criteria of posyandu cadres were those sick during the research.

Subjects who met the inclusion and exclusion criteria then filled out questionnaires on attitudes and knowledge prior to training. Next, a basic training on mental health was done by using a module. After that, the subjects returned the questionnaire about attitude and knowledge concerning mental disorders. Changes in attitude and knowledge before and after training were then analyzed using the Wilcoxon tests.

\section{RESULTS}

The study was conducted in Hargosari, Tanjungsari subdistrict, October 2016, with 45 research subjects meeting the inclusion and exclusion criteria.

Table 1. Characteristics of respondents

\begin{tabular}{lcc}
\hline \multicolumn{1}{c}{ Variable } & n & \% Min - Max \\
\hline Age of respondent & 3 & \\
18- 24 years & 14 & 6.7 \\
25-34 years & 27 & 31.1 \\
35-54 years & 1 & 60.0 \\
>55 years & 17 & 2.2 \\
Work & 10 & \\
$\quad$ Housewife & 15 & 37.8 \\
Entrepreneur & 3 & 22.2 \\
Farmers & 11 & 33.3 \\
$\quad$ Civil servants & 10 & 6.7 \\
Education & 14 & 24.4 \\
$\quad$ Primary school & 10 & 22.2 \\
Junior high school & & 31.1 \\
Senior High School & 15 & 22.2 \\
Bachelor & 29 & \\
How Long Being a cadre & 1 & 33.3 \\
1-5 years & & 64.4 \\
5-10 years & 35 & 2.2 \\
> 10 years & 9 & 77.8 \\
Socioeconomic status & 1 & 20.0 \\
<=1000000 & & 2.2 \\
1000000-3000000 & & \\
>=3000000 & &
\end{tabular}


Characteristics of subjects included age, occupation, education, how long being cadres and socioeconomic status (Table 1).

Table 2 shows that in the variables of age, occupation, education, how long being cadre and socioeconomic status, all show a significance of $p>0.05$, so it can be concluded that there was no significant difference between age, occupation, education, how long being cadres and socioeconomic status with changes in cadres knowledge after training.

Table 3 shows that in the variables of age, occupation, education, how long being cadre and socioeconomic

Table 2. ANOVA test of variable age, occupation, education, how long being cadre and socioeconomic status of knowledge change

\begin{tabular}{|c|c|c|c|}
\hline Variable & $\mathbf{n}$ & $\begin{array}{c}\text { Change of knowledge } \\
\text { Mean } \pm \text { SD }\end{array}$ & $p$ \\
\hline \multicolumn{4}{|l|}{ Age of respondent } \\
\hline $18-24$ years & 3 & $3.3 \pm 1.5$ & \multirow{4}{*}{0.28} \\
\hline $25-34$ years & 14 & $4.8 \pm 2.1$ & \\
\hline $35-54$ years & 27 & $3.6 \pm 2.3$ & \\
\hline$>55$ years & 1 & 2 & \\
\hline \multicolumn{4}{|l|}{ Work } \\
\hline Housewife & 17 & $4.1 \pm 2.4$ & \multirow{4}{*}{0.58} \\
\hline Entrepreneur & 10 & $4.4 \pm 1.9$ & \\
\hline Farmers & 15 & $3.8 \pm 2.5$ & \\
\hline Civil servants & 3 & $2.3 \pm 2.1$ & \\
\hline \multicolumn{4}{|l|}{ Education } \\
\hline Primary school & 11 & $3.5 \pm 1.9$ & \multirow[t]{4}{*}{0.39} \\
\hline Junior high school & 10 & $5.0 \pm 2.5$ & \\
\hline Senior High School & 14 & $3.9 \pm 2.4$ & \\
\hline Bachelor & 10 & $3.9 \pm 2.3$ & \\
\hline \multicolumn{4}{|l|}{ How Long being a cadre } \\
\hline $1-5$ years & 15 & $5.0 \pm 2.2$ & \multirow[t]{3}{*}{0.06} \\
\hline $5-10$ years & 29 & $3.5 \pm 2.1$ & \\
\hline$>10$ years & 1 & 2 & \\
\hline \multicolumn{4}{|l|}{ Socioeconomic status } \\
\hline$<=1000000$ & 35 & $3.9 \pm 2.2$ & \multirow[t]{3}{*}{0.36} \\
\hline $1000000-3000000$ & 9 & $3.5 \pm 2.4$ & \\
\hline$>=3000000$ & 1 & 7 & \\
\hline
\end{tabular}

Table 3. ANOVA test of variable age, occupation, education, how long being cadre and socioeconomic status of attitude change

\begin{tabular}{lccc}
\hline \multicolumn{1}{c}{ Variable } & $\mathbf{n}$ & $\begin{array}{c}\text { Change of attitude } \\
\text { Mean } \pm \text { SD }\end{array}$ & $\boldsymbol{p}$ \\
\hline Age of respondent & 3 & $12.3 \pm 4.9$ & 0.29 \\
18- 24 years & 14 & $8.9 \pm 3.9$ & \\
25-34 years & 27 & $8.1 \pm 4.8$ & \\
35-54 years & 1 & 3.0 & \\
$\quad>55$ years & 17 & $9.1 \pm 4.8$ & \\
Work & 10 & $7.5 \pm 5.3$ & \\
$\quad$ Housewife & 15 & $8.5 \pm 1.5$ & \\
Entrepreneur & 3 & $8.7 \pm 1.5$ & \\
Farmers & 11 & $8.7 \pm 5.1$ & \\
Civil servants & 10 & $8.0 \pm 4.7$ & \\
Education & 14 & $9.1 \pm 4.2$ & \\
$\quad$ Primary school & 10 & $7.9 \pm 4.9$ & \\
Junior high school & & & \\
Senior High School & 15 & $9.6 \pm 4.2$ & \\
Bachelor & 29 & $8.1 \pm 4.7$ & \\
How Long being a cadre & 1 & 3 & \\
1-5 years & & & \\
5-10 years & 35 & $8.5 \pm 5.0$ & \\
> 10 years & 9 & $8.2 \pm 3.1$ & \\
Socioeconomic status & 1 & 10 & \\
$\quad$ <=1000000 & & & \\
1000000-3000000 & & & \\
$>=3000000$ & & &
\end{tabular}

status, all show a significance of $p>0.05$, so it can be concluded that there was no significant difference between age, occupation, education, how long being cadres and socioeconomic status with changes in cadres attitude after training. 
Based on Table 4 for knowledge in the research group, from a total data of 45 , there were 42 results with positive scores and 3 with the difference of zero or equal to its value. This finding means that there were 42 scores indicating that for the cadre who was given the training, their knowledge was higher than before the training. The data also showed there were 3 cadres who were given training, and their knowledge was not different from before being given training.
For attitudes in the research group, from the total of 45 scores, there were none with negative scores, there were 45 with positive scores and there was none with zero difference or scores equal in value. This result means that there were 45 data indicating that for the cadre who was given the training, their attitude was higher than before being given training. This finding shows an increase in knowledge and attitude of all cadres toward mental disorders after being given mental health training.

Table 4. Ranks research group

\begin{tabular}{|c|c|c|c|c|}
\hline & & $\mathbf{n}$ & $\begin{array}{l}\text { Rank } \\
\text { Mean }\end{array}$ & $\begin{array}{c}\text { Sum of } \\
\text { Rank }\end{array}$ \\
\hline \multirow[t]{4}{*}{$\begin{array}{l}\text { Total knowledge of posttest - the amount of pretest } \\
\text { knowledge }\end{array}$} & $\begin{array}{l}\text { Negative } \\
\text { ranks }\end{array}$ & $0^{\mathrm{a}}$ & .00 & .00 \\
\hline & Positive ranks & $42^{b}$ & 21.50 & 903.00 \\
\hline & Ties & $3^{c}$ & & \\
\hline & Total & 45 & & \\
\hline \multirow[t]{4}{*}{$\begin{array}{l}\text { Total of posttest attitudes - the number of pretest } \\
\text { attitudes }\end{array}$} & $\begin{array}{l}\text { Negative } \\
\text { ranks }\end{array}$ & $0^{\mathrm{d}}$ & .00 & .00 \\
\hline & Positive ranks & $42^{\mathrm{e}}$ & 23.00 & 1035.00 \\
\hline & Ties & $3^{f}$ & & \\
\hline & Total & 45 & & \\
\hline
\end{tabular}

a. knowledge of posttest < pretest knowledge

b. knowledge of posttest $>$ pretest knowledge

c. knowledge of posttest $=$ pretest knowledge

d. posttest attitudes < pretest attitudes

e. posttest attitudes $>$ pretest attitudes

f. posttest attitudes $=$ pretest attitudes

Table 5 shows that since the significance value was $0.000(<0.05)$, then according to statistical methodology, the $\mathrm{H}_{0}$ is rejected and $\mathrm{H}_{1}$ accepted, supporting the basic hypothesis that there is a difference in knowledge and attitude of cadre between before and after received training. This finding suggests that cadre training on mental health has the effects of increasing the knowledge and attitude of cadres about mental disorders.

Table 5. Statistics test of research group ${ }^{b}$

\begin{tabular}{lll}
\hline & $\begin{array}{c}\text { Total knowledge of posttest - the } \\
\text { amount of pretest knowledge }\end{array}$ & $\begin{array}{c}\text { Total of posttest attitudes - the } \\
\text { number of pretest attitudes }\end{array}$ \\
\hline $\mathbf{Z}$ & $-5.670^{\mathrm{a}}$ & $-5.845^{\mathrm{a}}$ \\
Asymp. Sig. (2-tailed) & .000 & .000 \\
\hline
\end{tabular}

a. Based on negative ranks.

b. Wilcoxon Signed Ranks Test

\section{DISCUSSION}

Based on the results of the study it can be concluded that knowledge after training in mental health increased significantly. This result demonstrates that the mental health training provided by health workers for posyandu volunteer cadres was evidently effective.

Claudia's research shows that there was a significant increase in cadre knowledge after health education. Several factors were found to influence cadre knowledge on mental health including experience, exposure to media, economy, environment, social relations, access to health services, age, education, and employment ${ }^{12}$.

This study also reinforces the results of research by Champion which found that health education has a significant influence on the level of public knowledge in dealing people with mental disorders. Knowledge of the handling of mental disorders should be introduced earlier especially to family members of people with mental disorders ${ }^{13}$. Research by Pramujiwati showed that there is a close relationship between the change of signs and symptoms as well as increased ability to combine nursing actions and cadre empowerment ${ }^{14}$.

The combination of knowledge and attitude of cadres can effectively increase the role of volunteer cadres in the early detection of mental disorders in the community. This finding shows the role of cadres must be balanced with the knowledge and attitude of cadres in conducting socialization and early detection.

Limitations of this study include how the study population was still limited at the district level so the results cannot completely assess whether the finding can be applied everywhere in Gunungkidul. In addition, further research is needed to determine whether changes in attitude and knowledge can be maintained for a long period of time, 
not only immediately after training.

\section{CONCLUSIONS}

Based on the results of this study it can be concluded that there was a significant difference in the attitude of cadres after mental health training. This study also found that there was a significant difference in cadre knowledge after mental health training.

This study emphasizes that the posyandu volunteer cadres need to receive proper training on mental health to improve their attitudes and knowledge of mental disorders. Community participation and Primary Health Care Centers can play an active role in providing mental health training for the cadres in order to improve the early detection of mental disorders. Further research is required to measure in the future the activeness of cadres in reporting and referral of mental disorders to the Community and Primary Health Care Centers.

\section{Acknowledgment}

We thank to our friends at the technical service unit of the Community and Primary Health Care Center Tanjungsari which provided significant help in this research.

\section{Ethical and Informed Consent Approval}

This study was approved by The Medical and Health Research Ethics Committee (MHREC) of the Faculty of Medicine, Universitas Gadjah Mada, Yogyakarta, Indonesia in 2016.

\section{Funding}

Self-funding.

\section{Data and Material Availability}

Data and material access can be accessed via thecorresponding author.

\section{Conflict of Interest}

None.

\section{REFERENCES}

1. Prince M, Patel V, Saxena S, Maj M, Maselko J, Phillips MR, et al. No health without mental health. The Lancet. 2007 Sep 8;370(9590):859-77.

2. Munson MR, Floersch JE, Townsend L. Attitudes toward mental health services and illness perceptions among adolescents with mood disorders. Child and Adolescent Social Work Journal. 2009 Oct $1 ; 26(5): 447-66$.

3. Burns T, Kendrick T. The primary care of patients with schizophrenia: A search for good practice. Br J Gen Pract. 1997 Aug 1;47(421):51520.

4. World Health Organization. Investing in mental health. Geneva: WHO 2003.

5. World Health Organization. World health statistics. Geneva: WHO 2006.

6. Agency for Health Research and Development Ministry of Health Republic of Indonesia. Presentation of Basic Health Research Results. Jakarta: Agency for Health Research and Development Ministry of Health Republic of Indonesia. 2013.

7. Grilo CM, Sanislow CA, Gunderson JG, Pagano ME, Yen S, Zanarini $\mathrm{MC}$, et al. Two-year stability and change of schizotypal, borderline, avoidant, and obsessive-compulsive personality disorders. Journal of Consulting and Clinical Psychology. 2004 Oct;72(5):767.

8. Kasmel A, Andersen PT. Measurement of community empowerment in three community programs in Rapla (Estonia). International Journal of Environmental Research and Public Health. 2011 Mar $11 ; 8(3): 799-817$.
9. Khotimah NN, Hadi H. Evaluation of cadre activeness in nutrition program service at Posyandu years 2000 at 4 Community and Primary Health Care Center in Palembang [Doctoral dissertation]. Yogyakarta: Universitas Gadjah Mada; 2003.

10. Ministry of Health Republic of Indonesia. Guidelines for implementing community participatory approaches in improving the performance of Posyandu. Jakarta: Ministry of Health Republic of Indonesia. 2000.

11. Gunanti IR, Dewi SR, Andriani M. Empowerment of Posyandu cadres through the application of nutritional counseling methods in an effort to improve the quality of fostering nutrition awareness family programs (KADARZI). Health System Research Bulletin. 2005.

12. Claudia RA, Widodo A. The Influence of Provision of Health Education on Prevention of Infestation to Knowledge and Attitudes of Health Cadres in Mancasan Village [Doctoral dissertation]. Surakarta: Muhammadiyah Surakarta University; 2016.

13. Campion J, Bhui K, Bhugra D. European Psychiatric Association (EPA) guidance on prevention of mental disorders. European Psychiatry. 2012 Feb 1;27(2):68-80.

14. Pramujiwati D, Keliat BA, Wardani IY. Family empowerment and mental health cadres in handling low chronic self-esteem patients with Precede L. Green model approach in RW 06, 07 and 10 Tanah Baru North Bogor. Journal of Soul Nursing. 2013;1(2). 